\title{
LONG-TERM TRENDS IN FOOD CONSUMPTION: COMPARISON BETWEEN SERBIA AND GREECE
}

\author{
Tatjana Brankov ${ }^{1}$, Theodoros Markopoulos ${ }^{2}$, Stavros Kontakos ${ }^{3}$ \\ *Corresponding author E-mail:brankov.tatjana@gmail.com
}

\begin{abstract}
A R T I C LE IN F O
A B S T R A C T

Original Article

Received: 10 October 2019

Accepted: 02 December 2019

doi:10.5937/ekoPolj1904975B

UDC 338.439.63(497.11)(495)

Keywords:

Food Consumption, GDP, Economic Transition, Forecasts

This study analyses the relationship between food consumption and income, taking the consumption (per capita) of different food categories and GDP (per capita) as indicators. It presents the time series trends and compares the food consumption patterns for two countries - Serbia and Greece - an upper-middle income country outside of the EU and a high-income EU member country, respectively. The analysis showed that consumption of all food groups in Serbia (except milk) over two decades (1994-2016) is significantly affected by the changes in the GDP; while in Greece, only consumption of meat, fruits, grains, and sweetened products JEL: D12, E21 was positive or negative influenced by GDP. Trend analysis of the consumption of the different food categories showed huge differences between the two countries.
\end{abstract}

(C) 2019 EA. All rights reserved.

\section{Introduction}

Dietary changes associated with economic growth have been extensively studied in many countries (Monteiro et al., 2004; Popkin, 2001; Popkin, 2002; Popkin, 2006; Lipoeto et al., 2004; Janhs et al., 2003; Ghassemi et al., 2002; Kim et al., 2002; GerbensLeenes et al., 2010; Madanat et al., 2008; Burggraf et al., 2015). However, there is insufficient research available on nutritional changes in countries heavily affected by economic transitions (Ivanova et al., 2006), wars, disintegration and political crisis.

Thus, the first country we selected for the analyses was Serbia - a very particular case of middle-income countries: its economy has halved concerning the early 1990s. It is one of the economies in Central and Southeastern Europe (CEEs), whose system radically

1 Tatjana Brankov, PhD, Assistant Professor, University of Novi Sad, Faculty of Economics, Segedinski put 9-11, 24000 Subotica, Serbia, Phone: +381641021696, E-mail:brankov. tatjana@gmail.com ORCID ID 0000-0002-3675-6788

2 Theodoros Markopoulos, $\mathrm{PhD}$, Department of Oenology and Beverage Technology, Eastern Macedonia and Thrace Institute of Technology; Ag.Loukas, 65404 Kavala, Greece, E-mail: thamarkopoulos@yahoo.gr, ORCID ID 0000-0002-2745-7129

3 Stavros Kontakos, PhD, Department of Social Administration and Political Science, Democritus University of Thrace, 69100-Komotini, Greece, E-mail:skon2915dt@gmail. com, ORCID ID 0000-0001-9287-1775 
changes from the centrally planned to the market economy after the 1990s; country that indirectly experienced civil war (1991-1999), NATO bombing (March-June 1999), international economic sanctions (several rounds - 1992-1995; 1998-1999); an influx of about one million refugees, gray economy and the biggest hyperinflation after World War II (Brankov and Lovre, 2017). A severe downturn in a nation's economy and a radical increase in food prices (Lovre and Brankov, 2015) has affected a population's ability to get a healthful diet. A serious decline in dietary energy recorded: from $3,698 \mathrm{kcal} /$ capita/day in 1988 to 2,890 in 2011 (Brankov, 2018). As a result, the longterm health problems reflected in increased mortality from nutrition-related noncommunicable diseases (NCDs) occurred (Simic et al., 2010; Vujcic et al., 2013). Inadequate economic access to food is most probably one of the reasons for the black demographic situation: about 600,000 Serbs have left the country over the past 25 years (Brankov, 2018). Owing to the decline in domestic demand Serbia has preserved to a great extent its food self-sufficiency. There is a positive trade balance of agri-food products since 2005 (Zekic et al., 2013).

Contrary to Serbia, Greece joined the European Community in 1981, and since the end of the civil war in 1949, it has not experienced war on its territory (Kalaitzidis and Zahariadis, 2015). Consequently, the average dietary energy supply remains stable over time and amounts to more than 3,600 kcal/capita/day since the 1990s (FAO, 2015). According to the latest World Bank data Greece had in 2017, 3.8 times higher GDP per capita than Serbia; 23,027.4 vs 5,992.3 (constant 2010 US\$).

Apart from differences, there are significant similarities among these two countries starting from the evolution of the taxation system and institutions (Tuncer, 2017) to many cultural, and religious issues. Therefore, it seems reasonable to compare Serbia, which is under the process of accession to the EU, with Greece an 'old' EU member, for which it ties a lot.

The article explores several themes that relate to: (i) a broad overview of the dynamic shifts in diets; (ii) information that shows that the shift in stages of the nutrition transition in the developing world differs from developed world; (iii) information that shows that there are a market changes in diet concurrent with income increases.

\section{Materials and methods}

Input data collection

We used publicly accessible per capita food consumption data provided by the national statistical offices. Statistical Office of the Republic of Serbia provides estimates of quantities of consumed food and drink items in households by conducting the survey that covered the whole territory of the country (SORS, 2017). Two-stage of random sampling were used to generate a sample: first, random sampling in the districts was conducted; second, individual households were selected according to the sample plan. The survey covered between 6,457 and 8,896 households in estimated years, which correspondents to around $0.4 \%-0.5 \%$ of the total Serbian population. System of 
assessment was executed in a standard way applied for a two-stage stratified sample, i.e. the selection procedure for the first stage was in proportion to the size and repeated, while for the second stage it was simple random non-repeated selection.

Similarly, Greek data were provided from the Hellenic Statistical Authority (HSA). Data is derived from the annual Household Budget Survey (HBS). The data regarding the years 1994-2016 and they represent the monthly average of quantities of certain items (food, beverages, tobacco, and fuel) consumed by the household in the whole country.

Data analysis

This study firstly assesses the GDP changes over time in both countries. We applied both trend analysis and a forecast for the consumption of the majority food groups at a four years period. Secondly, we evaluate the relationship between GDP and consumption of specific food groups. The major variables - per capita income and quantity of foods were analyzed by the linear association between these variables using linear regression models having the variable of interest as the outcome and income (continuous variable) as the explanatory variable.

Food items selected for analysis included bread and bakery, flour and pasta, rice, fresh meat, meat products, fresh fish, fish products, eggs, milk, yogurt, white cheese, fresh fruit, processed fruit, fresh vegetables, processed vegetables, vegetable oil, animal fat, chocolate, cookies, biscuits. These items were grouped as follows: grains (i.e. bread, flour, and rice), meat (i.e. meat, meat products), milk (i.e. fresh milk, yogurt, cheese), vegetables (i.e. fresh vegetables, processed vegetables), fruits (i.e. fresh fruit, processed fruit), fats (i.e. oil, butter, margarine, lard), sweetened products (i.e. chocolate, cookies) and eggs. The data were calculated annually per capita and refers to the time frame of 1994-2016.

The autocorrelation plot was used to determine whether the time series were stationary or not. The appropriate autocorrelation plots showed that there were exist a trend in all the cases, both at Serbia and Greek time series. Thus, the appropriate model was fitted to create the forecasts for the next periods. All statistical analyses were conducted using Minitab statistical software.

\section{Results}

In Greece, we can observe that the upward trend of GDP seems to be halted in the year 2008, where it reached its peak, and after this year there is a downward trend until 2013, where it shows to be stabilized (Figure 1). 
Figure 1. The evolution of the GDP in Greece (left) and Serbia (right)
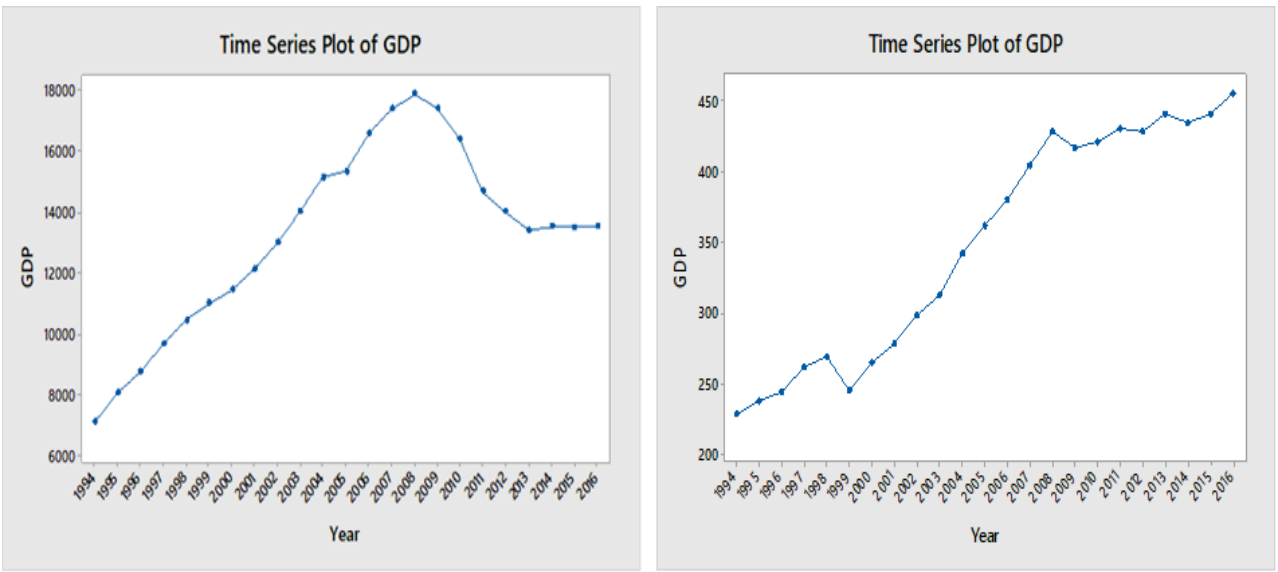

Source: Authors' calculation

Quite differently, the upward trend of GDP in Serbia can be observed until 1988, just before two years of the strong decline. After 2000 an upward trend in GDP has broken also in the year 2008, but recovery started very soon and, in the year 2011, it has outgrown the level reached in 2008. Figures 2 and 3 show the time series plot of the consumption of basic goods (in kilograms, except milk which is in liters and eggs which is the number of) compared to the time evolution of GDP in Serbia and Greece, respectively.

The numbers are referred to as the mean monthly consumption during the years 19942016. As could be seen from the time series plots (Figure 2) consumption of all food groups in Serbia, except grains, milk, and fats, increased by increasing GDP. This was valid until 2011 - after that period the food consumption did not correspond adequately with the increase of GDP. The issue is much clearer and more visible in the Greek case (Figure 3). The key feature of most of the time series plots is that the consumption of all the major goods is reduced about the same period in which there is a reduction of GDP. This could be explained by the fact that in this period (late 2008-2009) started in Greece the great economic crisis, which has changed dramatically many aspects of everyday life of the Greeks, one of which was the consumption of the basic foodstuffs.

Subsequently, and taking into account the form of the initial time series, trend analysis and a forecast for the consumption of the majority food groups was applied, for both countries. These analyses are shown initially in Figures 4 and 5. 
Figure 2. Relationship between GDP and food consumption in Serbia

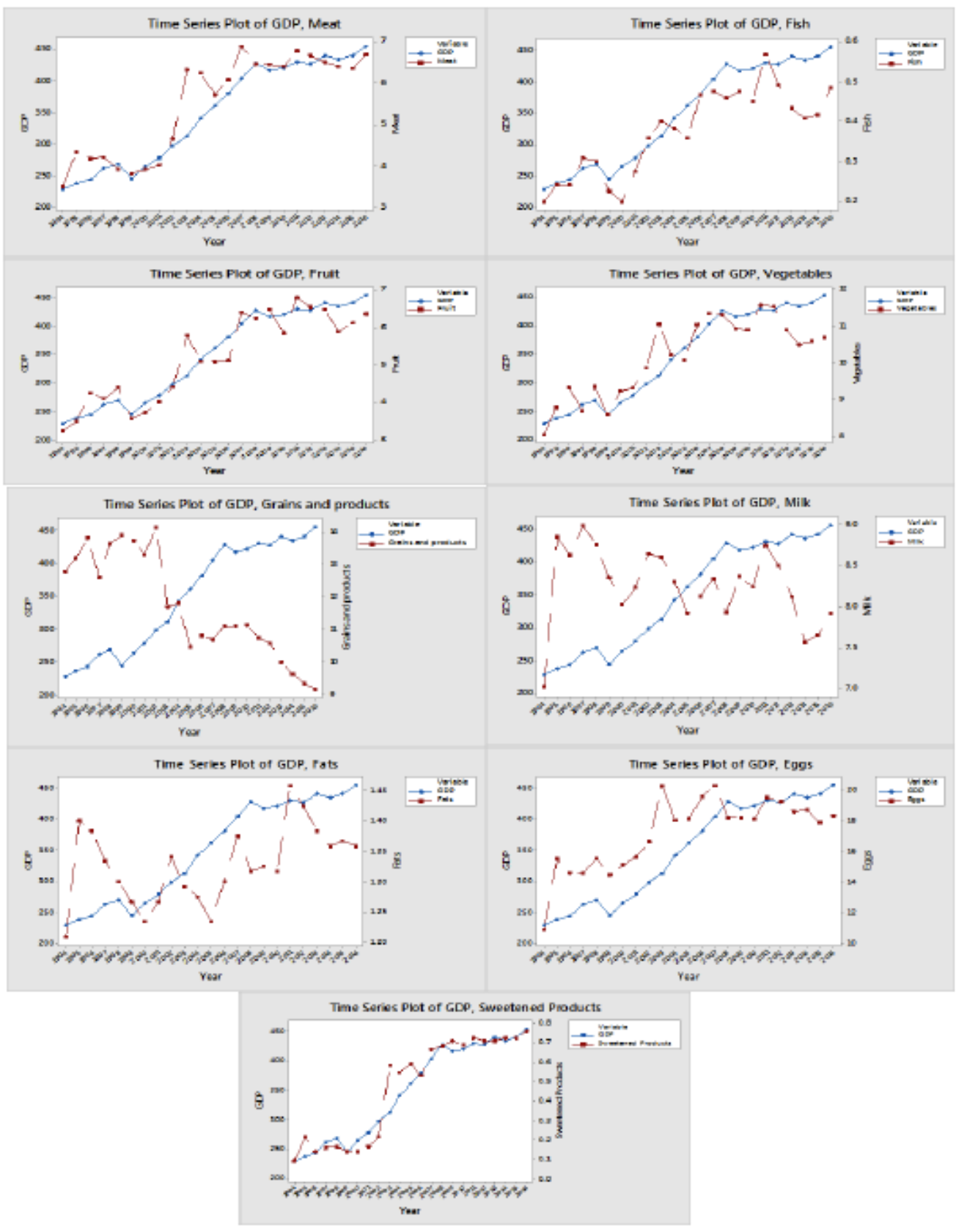

Source: Authors' calculation 
Figure 3. Relationship between GDP and food consumption in Greece

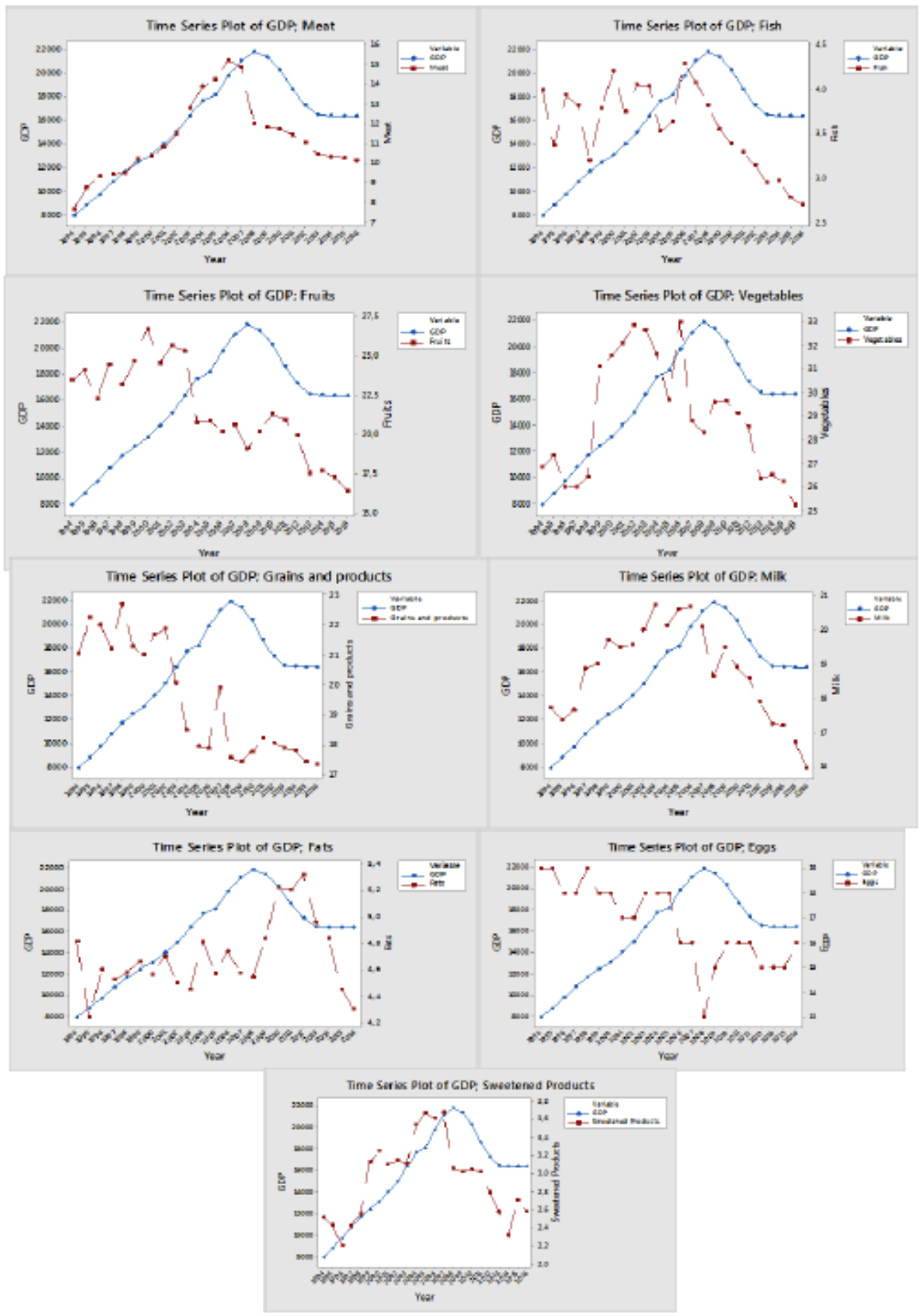

Source: Authors' calculation 
Figure 4. Serbian trends in dietary patterns (average quantity consumed monthly per household member on y axis)

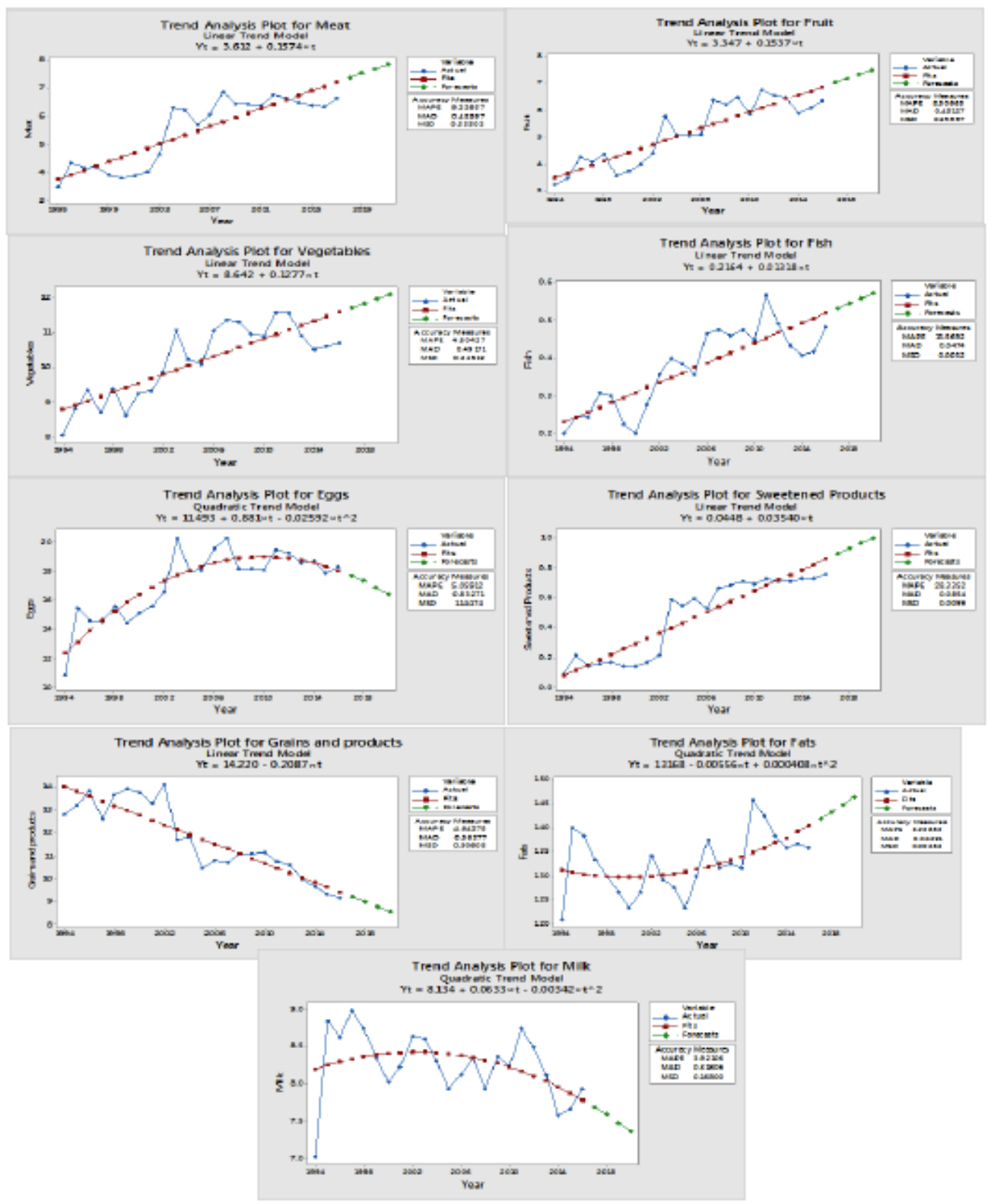

Source: Authors' calculation 
Figure 5. Greek trends in dietary patterns (average quantity consumed monthly per household member on y axis)

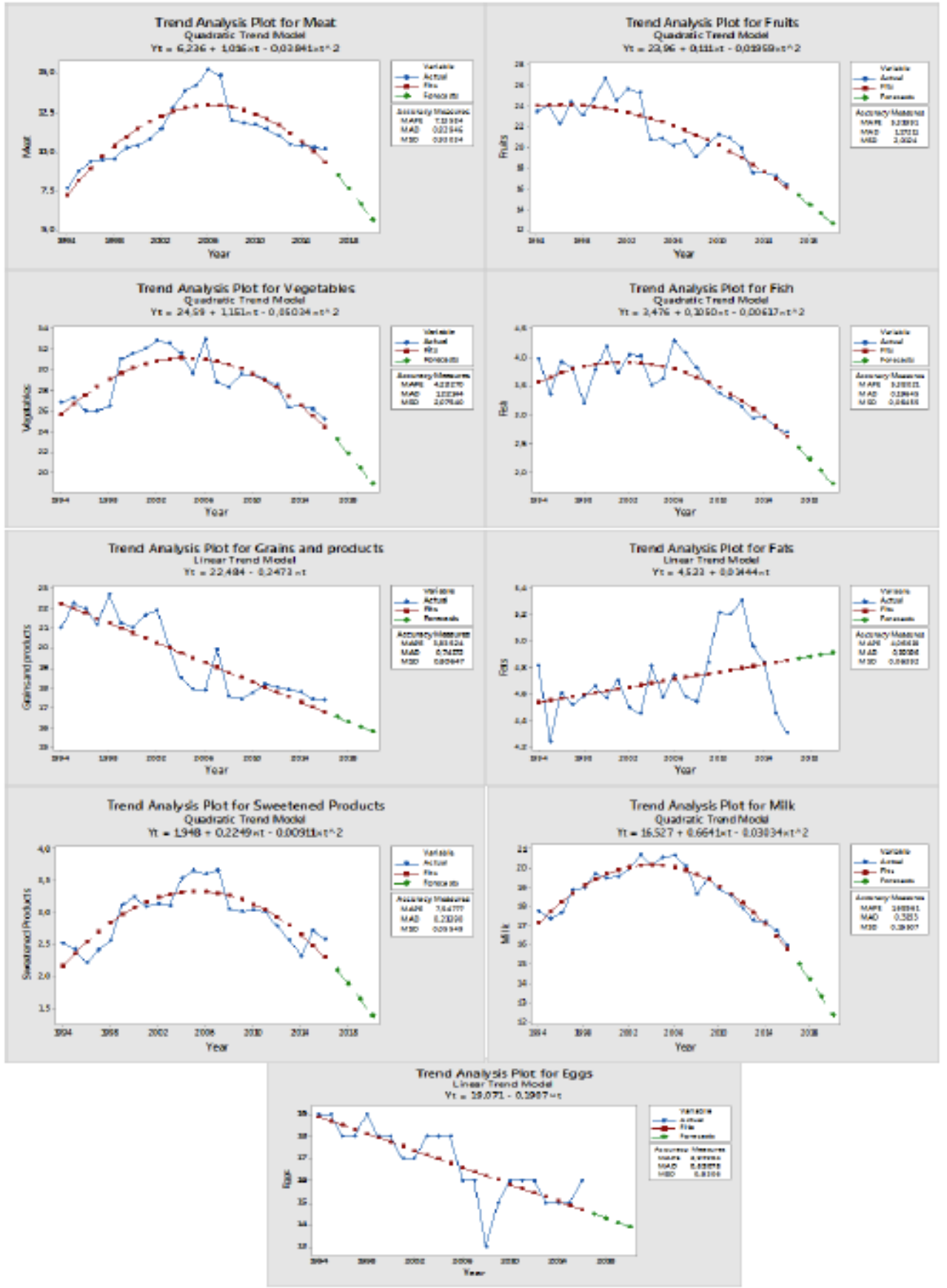

Source: Authors' calculation 
Moreover, to be more accurate, the exact forecast for the consumption of major food groups, for both countries, are presented in Tables 1 and 2 . The forecast was made for four years, i.e. the years 2017 to 2020 .

Table 1. Forecasts of the consumption of the basic products in Serbia, at a four years period (2017-2020) in monthly quantities on average, per household member (in kilograms except milk and eggs).

\begin{tabular}{|c|c|c|c|c|c|c|c|c|c|}
\hline & \multicolumn{9}{|c|}{ Consumption of the basic products } \\
\hline Year & Meat & Fruits & Fish & Vegetables & $\begin{array}{c}\text { Grains } \\
\text { and } \\
\text { products }\end{array}$ & $\begin{array}{c}\text { Milk } \\
\text { (in } \\
\text { liters) }\end{array}$ & Fats & $\begin{array}{c}\text { Eggs } \\
\text { (pieces) }\end{array}$ & $\begin{array}{c}\text { Sweet- } \\
\text { ened } \\
\text { Products }\end{array}$ \\
\hline 2017 & 7.389 & 7.035 & 0.533 & 11.707 & 9.211 & 7.683 & 1.418 & 17.708 & 0.894 \\
\hline 2018 & 7.547 & 7.189 & 0.546 & 11.835 & 9.002 & 7.578 & 1.432 & 17.319 & 0.929 \\
\hline 2019 & 7.704 & 7.343 & 0.559 & 11.962 & 8.793 & 7.467 & 1.448 & 16.879 & 0.965 \\
\hline 2020 & 7.861 & 7.496 & 0.572 & 12.090 & 8.585 & 7.349 & 1.464 & 16.386 & 1.001 \\
\hline
\end{tabular}

Source: Authors' calculation

Table 2. Forecasts of the consumption of the basic products in Greece, at a four years period (2017-2020) in monthly quantities on average, per household member (in kilograms except milk and eggs).

\begin{tabular}{|c|c|c|c|c|c|c|c|c|c|}
\hline & \multicolumn{9}{|c|}{ Consumption of the basic products } \\
\hline Year & Meat & Fruits & Fish & Vegetables & $\begin{array}{c}\text { Grains } \\
\text { and } \\
\text { products }\end{array}$ & $\begin{array}{c}\text { Milk } \\
\text { (in } \\
\text { liters) }\end{array}$ & Fats & $\begin{array}{c}\text { Eggs } \\
\text { (pieces) }\end{array}$ & $\begin{array}{c}\text { Sweet- } \\
\text { ened } \\
\text { Products }\end{array}$ \\
\hline 2017 & 8.500 & 15.335 & 2.441 & 23.220 & 16.548 & 14.988 & 4.869 & 14.494 & 2.097 \\
\hline 2018 & 7.634 & 14.486 & 2.243 & 21.904 & 16.300 & 14.165 & 4.883 & 14.303 & 1.876 \\
\hline 2019 & 6.692 & 13.598 & 2.033 & 20.488 & 16.053 & 13.283 & 4.898 & 14.112 & 1.636 \\
\hline 2020 & 5.672 & 12.670 & 1.811 & 18.971 & 15.806 & 12.338 & 4.912 & 13.921 & 1.378 \\
\hline
\end{tabular}

Source: Authors' calculation

The consumption of the majority of food groups - meat, fish, dairy, eggs, fruits, vegetables, and sweetened products - in Serbia increased during the observed period. A particularly large increase was reported for sweetened products (250\%), fish (100\%), and fruits $(81.7 \%)$. Analysis of the data showed that there was a significant decrease in the consumption of grains $(30.5 \%)$, while the overall consumption of fats and milk did not change. However, the overall consumption of the majority of food items in Serbia is much lower than in Greece. This trend will continue in the future also (Table 1-2). The exceptions can only be observed in the consumption of meat and eggs. It can be expected that Serbia will spend more meat and eggs per capita than in Greece shortly.

Simple linear regression analyses were used in Serbian and Greek data to determine the relationship between GDP and food consumption (Tables 3 and 4). 
Table 3. Simple linear regression analyses to determine the relationship between GDP and food consumption in Serbia

\begin{tabular}{|l|l|l|l|l|l|}
\hline & & & & & \\
\hline Independent: GDP $p c$ & $\mathrm{R}^{2}(\%)$ & $\operatorname{Adj~}^{2}(\%)$ & $\mathrm{F}$ & $\mathrm{p}$ & Regression equation \\
\hline \multicolumn{5}{|l|}{} & \multicolumn{5}{l|}{} \\
\hline Dependent variable & \multicolumn{5}{|l|}{} \\
\hline Meat & 86.6 & 86.0 & 135.96 & 0.000 & $\mathrm{y}=7.863+0.1667 \mathrm{x}$ \\
\hline Fruits & 88.8 & 88.3 & 166.96 & 0.000 & $\mathrm{y}=6.110+0.1611 \mathrm{x}$ \\
\hline Vegetables & 78.1 & 77.1 & 75.03 & 0.000 & $\mathrm{y}=74.37+0.1368 \mathrm{x}$ \\
\hline Fish & 82.5 & 81.7 & 99.31 & 0.000 & $\mathrm{y}=-0.4646+0.01422 \mathrm{x}$ \\
\hline Grains & 82.7 & 81.9 & 100.43 & 0.000 & $\mathrm{y}=214.7-0.2126 \mathrm{x}$ \\
\hline Fats & 21.7 & 18 & 5.83 & 0.025 & $\mathrm{y}=14.40+0.004357 \mathrm{x}$ \\
\hline Eggs & 63.5 & 61.7 & 36.46 & 0.000 & $\mathrm{y}=111.8+0.2709 \mathrm{x}$ \\
\hline Milk & 6.2 & 1.7 & 1.38 & 0.253 & $\mathrm{y}=104.8-0.01675 \mathrm{x}$ \\
\hline Sweetened products & 92.5 & 92.2 & 260.47 & 0.000 & $\mathrm{y}=-7.215+0.03684 \mathrm{x}$ \\
\hline
\end{tabular}

Source: Authors' calculation

Table 4. Simple linear regression analyses to determine the relationship between GDP and food consumption in Greece

\begin{tabular}{|c|c|c|c|c|c|}
\hline $\begin{array}{l}\text { Independent: } \\
G D P \text { pc }\end{array}$ & R-sq (\%) & $\begin{array}{l}\text { R-sq (adj) } \\
(\%)\end{array}$ & $\mathrm{F}$ & $\mathrm{p}$ & Regression equation \\
\hline \multicolumn{6}{|c|}{ Dependent variable } \\
\hline Meat & 60.45 & 58.57 & 32.10 & 0.000 & $\mathrm{y}=5.40+0.000370 \mathrm{x}$ \\
\hline Fruits & 28.97 & 25.28 & 8.56 & 0.029 & $\mathrm{y}=27.71+0.000388 \mathrm{x}$ \\
\hline Vegetables & 13.37 & 4.70 & 2.07 & 0.165 & $y=26.02+0.00186 x$ \\
\hline Fish & 12.10 & 3.31 & 0.17 & 0.687 & $\mathrm{y}=3.734+0.00002 \mathrm{x}$ \\
\hline Grains & 61.86 & 60.04 & 34.06 & 0.001 & $\mathrm{y}=25.32-0.00369 \mathrm{x}$ \\
\hline Fats & 12.14 & 7.96 & 2.90 & 0.948 & $y=-4.325+0.00024 x$ \\
\hline Eggs & 57.79 & 53.57 & 13.69 & 0.668 & $y=20.67-0.011 x$ \\
\hline Milk & 8.67 & 4.32 & 1.99 & 0.173 & $\mathrm{y}=17.26+0.00098 \mathrm{x}$ \\
\hline $\begin{array}{l}\text { Sweetened } \\
\text { products }\end{array}$ & 36.00 & 32.95 & 11.81 & 0.002 & $y=1.916+0.0065 x$ \\
\hline
\end{tabular}

Source: Authors' calculation

The analysis confirms previous expectations about the nutritional transition occurring in both developed and developing countries. But, in terms of calories arising from different major food commodities, large differences may be seen between the developing and developed countries. The overall consumption of foods in a developed country (Greece) is higher than in developing countries (Serbia). On a per-capita basis, the Greeks consume twice as much milk, fruits, and vegetables as the Serbs; they consume 3.5 times more fats and 4.5 times more fish. An exception that predicts that the Serbs will consume more meat and eggs shortly, can be explained by two facts. First, in 
developed countries such as Greece, the consumption of particular food items must reach the ceiling at some point, followed by an imminent decline. Second, Serbia has traditionally been able to ensure self-sufficiency in meat production, especially in pork.

\section{Discussions}

The analysis showed (Table 3 ) that consumption of all food groups in Serbia - except milk- are significantly affected by the changes in the GDP. Meat, fish, eggs, fruit, vegetables, sweetened products are all positively correlated with GDP, while grains are only negatively correlated. The same analysis for Greece showed (Table 4) that only the consumption of meat, fruits, grains, and sweetened products is significantly affected by the changes in the GDP. GDP has a positive impact on the consumption of meat, fruits, and sweetened products, while GDP seems to have a negative effect on the consumption of grain products.

Although both countries have a long-standing culinary tradition, they have also its unique gastronomical tradition and coping with modernization trend by the promotion of traditional food (Barjolle et al., 2015; Trichopoulou et al., 2006). Serbian cuisine was created under influence of Greek, Turkish and Hungarian cuisine. A lot of food items is homemade including: jams, pickled food, kajmak (clotted cream), milk cheeses, ajvar (eggplant and pepeper relish), rakija (fruit brendy), soups etc. Also, each region having its traditional dishes. Generally, Serbs are consuming a lot of processed meat such as meze (an assortment of small dishes and appetizers, slices of cured meats and sausages). Greeks adopt the Mediterranean diet, with some typical products such as wild plants, figs stuffed with walnuts (Simopoulos, 2001), feta, Greek salad etc. This kind of diet implies plenty of fruits and vegetables, olive oil, whole grains, and seafood. Therefore, differences in food patterns between two countries cannot be explained just by a large difference in GDP. An important role, certainly played - tradition. However, no doubt, the economic collapse of Serbia has caused great consequences and increased poverty in this country. This article foreseen that years would pass before fruits, vegetables, fish, and fats consumption in Serbia reaches a Greek level.

\section{Conclusions}

A reference should be done to the two events that decisively influenced the two countries, namely the bombings that took place in Serbia and the economic crisis facing Greece in recent years. For Serbia is concerned, there seems to be a strong tendency to increase food consumption in all categories, since the country is getting far away from that time. While in Greece the prolonged economic crisis seems to be causing a reduction in food consumption.

Consumption of food categories is influenced to some extent by other factors. In any case, the resumption of research in the future may give us a fuller picture of the evolution of food consumption in the two countries as they interact with the economic issues, the tradition of the two peoples and the evolution of consumer preferences. 
These results, the first of their sort to be estimated for Serbia, could be used for policy purposes, especially to assess the implications of obligations that the Republic of Serbia undertake through the Stabilization and Association Agreement (SAA) with the European Union (EU).

\section{Acknowledgements}

Paper is a part of research within the project no. III 46006- Sustainable agriculture and rural development in the function of accomplishing strategic objectives of the Republic of Serbia in the Danube region, financed by the Ministry of Education, Science and Technological Development of the Republic of Serbia.

\section{Conflict of interests}

The authors declare no conflict of interest.

\section{References}

1. Barjolle D., Brecic R., Cerjak M., Giraud, G. (2015). Traditional Food in Western Balkan Countries Consumers' Perceptions and Habits. 145th EAAE Seminar "Intellectual Property Rights for Geographical Indications: What is at Stake in the TTIP?” Parma, Italy.

2. Brankov T., Lovre, I. (2017). Food security in the former Yugoslav republics. Economics of Agriculture, 64(2): 701-721.

3. Brankov T. (2018). Food Policy in the Republic of Serbia. Reference Module in Food Science. Elsevier, 1-4. DOI: http://dx.doi.org/10.1016/B978-0-08-1005965.22394-9.

4. Burggraf C., Kuhn L., ZHAO Q.R., Teuber R., Glauben T. (2015). Economic growth and nutrition transition: an empirical analysis comparing demand elasticities for foods in China and Russia. Journal of Integrative Agriculture, 14(6): 1008-1022. DOI: https://doi.org/10.1016/S2095-3119(14)60985-0.

5. FAO, 2015. FAO Statistical Pocketbook. Rome, Italy.

6. Gerbens-Leenes P.W., Nonhebel S., Krol M.S. (2010). Food consumption patterns and economic growth. Increasing affluence and the use of natural resources. Appetite, 55(3): 597-608. DOI: https://doi.org/10.1016/j.appet.2010.09.013.

7. Ghassemi H., Harrison G., Mohammad K. (2002). An accelerated nutrition transition in Iran. Public health nutrition, 5(1a): 149-155. DOI: https://doi.org/10.1079/ PHN2001287.

8. Jahns L., Baturin A., Popkin B.M., (2003). Obesity, diet, and poverty: trends in the Russian transition to market economy. European journal of clinical nutrition, 57(10): 1295-1302. 
9. Ivanova L., Dimitrov P., Ovcharova D., Dellava J., Hoffman D. J. (2006). Economic transition and household food consumption: a study of Bulgaria from 1985 to 2002. Economics \& Human Biology, 4(3): 383-397. DOI: https://doi.org/10.1016/j. ehb.2006.08.001.

10. Kalaitzidis A., Zahariadis N. (2015). Greece's Trouble with European Union Accession. Cahiers de la Méditerranée, 90: 71-84.

11. Kim S., Moon S., Popkin B.M. (2000). The nutrition transition in South Korea. The American journal of clinical nutrition, 71(1): 44-53. DOI: https://doi.org/10.1093/ ajcn/71.1.44.

12. Lipoeto N. I., Wattanapenpaiboon N., Malik A., Wahlqvist M.L. (2004). Nutrition transition in west Sumatra, Indonesia. Asia Pacific journal of clinical nutrition, 13(3): 312-316.

13. Lovre K., Brankov T. (2015). The supermarket revolution in the Balkan countries: The case of Serbia. Agroeconomia Croatica, 5(1): 1-10.

14. Madanat H.N., Troutman K.P., Al-Madi B. (2008). The nutrition transition in Jordan: the political, economic and food consumption contexts. Promotion \& education, 15(1): 6-10. DOI: https://doi.org/10.1177/1025382307088092.

15. Monteiro C.A., Moura E.C., Conde W.L., Popkin B.M. (2004). Socioeconomic status and obesity in adult populations of developing countries: a review. Bulletin of the World Health Organization, 82: 940-946.

16. Popkin B.M. (2001). Nutrition in transition: the changing global nutrition challenge. Asia Pacific journal of clinical nutrition, 10: S13-S18. DOI: https://doi. org/10.1046/j.1440-6047.2001.0100s1S13.x.

17. Popkin B.M. (2002). The shift in stages of the nutrition transition in the developing world differs from past experiences! Public health nutrition, 5(1A): 205-214.

18. Popkin B.M. (2006). Global nutrition dynamics: the world is shifting rapidly toward a diet linked with noncommunicable diseases-. The American journal of clinical nutrition, 84(2): 289-298. DOI: https://doi.org/10.1093/ajcn/84.2.289.

19. Simić S., Milićević M. Š., Matejić B., Marinković J., Adams O. (2010). Do we have primary health care reform? The story of the Republic of Serbia. Health policy, 96(2): 160-169. DOI: https://doi.org/10.1016/j.healthpol.2010.01.015.

20. Simopoulos, A.P. (2001). The Mediterranean diets: what is so special about the diet of Greece? The scientific evidence. The Journal of nutrition, 131(11): 3065S-3073S. DOI: https://doi.org/10.1093/jn/131.11.3065S.

21. Trichopoulou A., Vasilopoulou E., Georga K., Soukara S., Dilis, V. (2006). Traditional foods: Why and how to sustain them. Trends in Food Science \& Technology, 17(9): 498-504. DOI: https://doi.org/10.1016/j.tifs.2006.03.005. 
22. Tuncer A.C. (2017). Conditionality, Fiscal Rules and International Financial Control in the European Periphery before 1914. In: Cardinale, I., Scazzieri, R. (Eds.). The political economy of the Eurozone. Cambridge University Press, Cambridge, 96-129.

23. Vujcic I.S., Sipetic S.B., Dubljanin E.S., Vlajinac H.D. (2013). Trends in mortality rates from coronary heart disease in Belgrade (Serbia) during the period 19902010: a joinpoint regression analysis. BMC cardiovascular disorders, 13(1): 112.

24. Zekic S., Gajic M., Matkovski B. (2013). Serbian agriculture in the regional and European integratons. In: Tomic, D., Sevarlic, M., Lovre, K., Zekic, S. (Eds.), 135 EAAE Seminar Challenges for the Global Agricultural Trade Regime after Doha. DAES, Belgrade, 369-376. 